\title{
A MORAL DE DEUS: DÁDIVA E HUMANIDADE NA VERSÃO APANJEKRA DO CRISTIANISMO
}

\author{
Bruno Nogueira Guimarães ${ }^{1}$ \\ ${ }^{1}$ Fundação Oswaldo Cruz, Escola Nacional de Saúde Pública Sergio Arouca, \\ Manguinhos, RJ, Brasil
}

Neste artigo, pretendo analisar algumas das interpretações dos Apanjekra da relação que estabelecem com o cristianismo, abordando a interação dos indígenas com os missionários. Para isto, narro um culto evangélico ocorrido em 2013 na aldeia Porquinhos, onde habitam os Apanjekra (na TI Porquinhos - MA), tratando dos encontros e dos desencontros no entendimento entre as partes. Os equívocos que surgem desta relação não decorrem apenas de um problema de comunicação, mas de pressupostos ontológicos e cosmológicos distintos (Viveiros de Castro 2004). A partir da fala de missionários e indígenas, demonstro que o que significa ser "crente" é radicalmente distinto para cada grupo, o que se expressa nas noções de pessoa e em suas implicações éticas concorrentes. Por fim, avanço a ideia de que aos Apanjekra interessa menos o telos cristão do que o código moral dos missionários, do qual fazem uso circunstancial com fins de estabilização corporal e manutenção do parentesco.

\section{Primeiros cristãos}

Na primeira metade do século XX, Curt Nimuendajú escreveu que

Os Ramkokamekra e os Apanjekra até o momento não tiveram missionários católicos ou protestantes. O conhecimento que possuem do cristianismo resulta da observação de neobrasileiros e dos esforços ocasionais e rudimentares desses vizinhos na imposição de suas ideias. No entanto, a possibilidade de adoção da fé alienígena é inconcebível para estes indígenas [...].

Os índios [Canela] sabem os nomes de meia dúzia de santos, mas não possuem qualquer noção a respeito de suas personalidades ou da de Jesus; esses nomes, como o do Diabo, figuram meramente no emprego retórico de suas 
falas em português, padronizadas pelos modelos neobrasileiros. Eles são, portanto, bastante indiferentes às figuras da fé cristã. Ao contrário dos Xerente, eles não buscaram identificar os personagens da fé cristã com contrapartes aborígenes (1946:242).

Por muito tempo, a relação dos índios Canela (nome que reúne os povos Apanjekra e Ramkokamekra) com o cristianismo foi marcada por contatos superficiais, intervalos e um conhecimento indireto, adquirido a partir da relação com colonizadores que não pertenciam a missões religiosas. Durante o período colonial, a prática dos "descimentos" foi pouco empregada com os povos Timbira, mesmo que tenha sido um dos principais métodos de catequização, pacificação e expansão coloniais no restante do Brasil (Perrone-Moisés 1992:118-9; Melatti 1967:23-4). No início da colonização do território timbira pelos criadores de gado, no século XVIII, a resistência indígena, a mobilidade dos nativos e as escaramuças dos invasores (Paula Ribeiro 2002) dificultavam a atividade missionária no Sertão dos Pastos Bons (Melatti 1967). No início do século XIX, os Canela, ${ }^{1}$ após sequências de batalhas e acordos de paz quebrados pelos invasores, migraram em direção à serra de Alpercatas, dificultando a evangelização e tornando o Regimento das Missões, de 1845, inócuo no tratamento dos povos da região (ver Carneiro da Cunha 1992; Hemming 2009:233-8; Kodama 2009:249-55). Os poucos capuchinos das missões em Barra do Corda e Grajaú que tentaram converter os Timbira na segunda metade do século não obtiveram qualquer sucesso, e entre os Krahô as atividades do último evangelizador católico remontam ao final do século XIX (Melatti 1967:44-5).

Nas últimas décadas do século XIX, membros do clero buscaram levar jovens das aldeias aos conventos, poupando o trabalho eclesiástico no território indígena. ${ }^{2}$ Estima-se que, em 1901, aproximadamente 40 índios canela estavam em internatos em Barra do Corda, quando os Guajajara atacaram posseiros, padres e freiras nas imediações da cidade. O poder público se aliou aos Canela para derrotar os inimigos, mas, após a batalha, ao invés de os laços com a congregação religiosa se estreitarem, os Canela abandonaram o convento (Crocker 1990:70-1). Crocker afirma que "uma parcela significativa do catolicismo nativo presente na tribo tem suas raízes nos conhecimentos difundidos pelos estudantes que regressaram do internato". É importante notar que as interações dos Timbira com as instituições religiosas e com as seculares não eram plenamente separadas: era por meio dos padres que chegavam aos indígenas tanto a educação formal (voltada para a alfabetização) como os "brindes dos civilizados", enviados pelos governos imperial e provincial (Melatti 1967:45). Como se verá, estas dádivas terão implicações para a percepção histórica da relação com os missionários. 
Nimuendajú viu a cisão entre o clero e os Timbira, no início do século $\mathrm{XX}$, mais como uma questão de desinteresse do que de insegurança: "a principal razão é a atitude negativista para com a cultura indígena que eles confrontam. Eles sentem que possuem atividades mais importantes do que estudar superstições nativas tolas ou seus costumes" (1946:241). Após os eventos marcantes do século XIX, ao longo do século seguinte a relação dos Canela com os missionários católicos foi episódica, mesmo que recorrente. Por décadas, indígenas se relacionaram com membros do clero que não viveram entre eles nem trabalharam ardorosamente por sua conversão. Antes, expunham elementos da cosmologia e doutrina católica, atualizando as narrativas orais das experiências das gerações anteriores.

Um período novo na relação dos Apanjekra (atuais habitantes da TI Porquinhos e aldeia homônima) com o cristianismo se deu com a chegada dos missionários Jack e Josephine Popjes, que viveram entre os Canela entre 1968 e 1990. Contudo, o casal do Summer Institute of Linguistics esteve a maior parte desse período na aldeia de Escalvado, dos Ramkokamekra, e suas atividades religiosas se concentraram nesta aldeia. Com uma população três vezes inferior a Escalvado, Porquinhos recebeu menor atenção dos evangelizadores. Se Crocker afirmou que os Ramkokamekra incorporaram personagens cristãos em sua cosmologia, a exemplo do Diabo (Crocker 1990:82), o mesmo não ocorreu com os Apanjekra, que raramente permitiram que missionários vivessem entre eles. A história do contato dos Apanjekra com pregadores cristãos é marcada por longos intervalos em que o proselitismo religioso era ocasional ou esbarrava na peculiar resistência indígena a ele: sem impedir missionários de visitarem suas aldeias, os Apanjekra evitavam que esses forasteiros permanecessem indefinidamente em seu território, como até hoje ocorre.

Desde a saída do casal do SIL da aldeia de Escalvado, poucos missionários residiram entre os Canela, sempre por períodos curtos. Atualmente, os membros das duas frentes evangélicas que atuam com maior dedicação ao proselitismo entre esses povos Timbira residem em Barra do Corda, ${ }^{3}$ não tendo autorização dos indígenas para habitar em Porquinhos: os Apanjekra recebem os visitantes, mas não esperam que eles permaneçam por vários dias.

Não tendo conhecido nenhum processo de conversão religiosa massiva, ${ }^{4}$ o cristianismo junto aos Canela atraiu pouca atenção dos estudiosos. Ao contrário de outros povos Jê, que adotaram um conjunto de práticas e discursos facilmente identificáveis pelos antropólogos como pertencentes ao arcabouço religioso do colonizador, como cultos, a leitura da Bíblia e a condenação do pecado, ${ }^{5}$ os Apanjekra e os Ramkokamekra não parecem ter nas investidas missionárias um grande fator de mudança social. Eles 
não concebem sua relação com o cristianismo a partir de uma ruptura com um estado anterior de pecado (Robbins 2004, 2007; Vilaça 2016), tampouco baseiam o exercício cristão no florescimento de um "eu interior", que se torna o cerne da nova noção de pessoa (Robbins, Schieffelin \& Vilaça 2014).

O argumento que será desenvolvido é o de que as possíveis transformações que são fruto da interação dos Apanjekra com o cristianismo não se resumem às práticas citadas acima, operando em outro registro, relacionado à produção corporal a partir de um comportamento moral específico. Para tanto, tomarei como ponto central da análise a visita de uma comitiva evangélica a Porquinhos. A descrição etnográfica do evento não terá como fim produzir uma concepção generalista do cristianismo entre os Apanjekra, e sim apontar para alguns eixos mobilizados pelos indígenas em sua própria avaliação do evento vivido por eles. Assim, explorarei o permanente processo de produção de significado sobre a experiência com os brancos e com os missionários, dialogando com outros contextos etnográficos e com formulações teóricas da etnologia e da antropologia do cristianismo. Como colocado por Gow (2009), o objetivo aqui não é ver o que o cristianismo faz aos indígenas, e sim como estes se apropriam do cristianismo.

\section{Duplo evento: o culto e a dádiva}

Primeiro de novembro de 2013: ao entardecer, chegaram à aldeia dos Apanjekra três picapes carregadas com mantimentos, roupas e remédios. Nelas estavam presentes Maria, ${ }^{6}$ a sua secretária, um major do exército, dois soldados, um pastor evangélico e um cantor gospel. Traziam à aldeia microfones, alto-falantes e caixas de som. Estacionaram os automóveis junto ao Posto de Saúde, na parte externa do círculo periférico da aldeia, para onde dezenas de pessoas correram para recebê-los. As crianças, curiosas, observavam à distância os forasteiros. Fugiram quando Maria as procurou pedindo beijos e abraços, frustrando os planos da secretária de fotografar sua chefe acalentada pelos infantes. Os membros das Forças Armadas conversavam com a enfermeira, em frente ao Posto, para onde o pastor e o cantor levavam as suas bagagens, e a eles se juntaram as lideranças indígenas.

O major solicitou aos principais da aldeia um local seguro para armazenar as doações de cestas básicas e vestuário que trouxeram para Porquinhos: procurava uma construção que pudesse ser trancada e tivesse acesso restrito, para não haver risco de furtos. Indicaram-lhe uma pequena casa próxima ao Posto, utilizada para armazenar a merenda escolar que recebem da Secretaria de Educação. Resolvido o problema de onde pernoitaria cada 
pessoa e cada coisa, o major apresentou os pastores aos Apanjekra e explicou às lideranças que na próxima manhã fariam os atendimentos médicos e distribuiriam os presentes. Maria, a responsável pela comitiva, aproveitava o momento para registrar sua chegada à aldeia junto às lideranças através das lentes de sua secretária.

Como a maioria dos forasteiros que visita Porquinhos, a comitiva ficou hospedada junto às construções dos kupen, como os não indígenas são chamados (por oposição aos Timbira, que referem a si próprios como mehin). ${ }^{7}$ É um agregado de casas de alvenaria localizado em uma das saídas da aldeia, atrás do último círculo de residências dos Apanjekra, onde moram os professores e as enfermeiras kupen, que são vistos pelos mehin como pouco participativos nas atividades de Porquinhos: não frequentam as reuniões diárias no centro da aldeia, não contribuem para a realização de festas, não compartilham seus alimentos com os indígenas e não dominam a língua timbira.

Às 6 horas da manhã do segundo dia de novembro, Maria e seus companheiros participaram da reunião no pátio da aldeia, atendendo ao convite dos Apanjekra. Explicaram que estavam ali para ajudar os índios, que trouxeram doações recebidas em Imperatriz pela congregação religiosa de que fazem parte, o Serviço de Evangelização Tocantins e Araguaia (Seta), integrante da pentecostal Convenção Geral das Assembleias de Deus no Brasil. ${ }^{8}$ Maria contou sua história: mulher de um oficial do Exército, descobriu há poucos anos que "era Canela" quando, ao estudar a própria árvore genealógica, notou que uma bisavó provinha das imediações da atual Terra Indígena Porquinhos. ${ }^{9}$ Desde então, iniciou um processo de busca por "sua família" e anunciava querer colocar o sobrenome "Canela" em seu registro geral e demais documentos, como ocorre com os indígenas. ${ }^{10}$ Estava ali para ter contato com "seus parentes" e levar a palavra de Deus. Maria anunciou que as consultas médicas aconteceriam ainda pela manhã; de tarde, realizariam o culto, seguido pela distribuição de presentes para as famílias e lanche para as crianças.

Esta não era a primeira visita da comitiva de Maria à aldeia. Contudo, por alguma razão, ainda não tinham nomes ou parentes junto aos Apanjekra. A prática de nominação, que estabelece laços de parentesco e localiza socialmente os forasteiros na aldeia, ${ }^{11}$ só ocorreria mais tarde naquele dia, por volta das 15h, antecedendo o culto; dela participariam cinco membros do grupo de Maria, excetuando-se o pastor e o cantor gospel.

Após a reunião, um grande número de habitantes da aldeia Porquinhos foi até as imediações do posto de saúde e da escola receber atendimento médico dos membros do Exército. Os Apanjekra não conseguiam precisar 
a última vez que os médicos da Secretaria Especial de Saúde Indígena foram à aldeia, e a falta de remédios se tornara um problema constante nos últimos anos. Fardados, os militares penduraram banners das Forças Armadas na escola, apesar de estarem ali em "missão extraoficial", como um deles me disse. Atenderam a dezenas de pessoas, distribuindo receitas médicas e remédios.

Enquanto isso, Maria caminhava pelo círculo periférico de Porquinhos tentando recensear os habitantes, registrando suas residências e composições familiares para organizar a distribuição dos bens. Nas três outras vezes em que estiveram na aldeia (uma por semestre no período que antecedera esta visita), ela me relatou, não conseguiram distribuir apropriadamente o que levaram, sempre faltando ou sobrando presentes. Desta vez, ela estava interessada em entregar uma cesta básica por casa, e havia pensado em visitar cada moradia para realizar as doações in loco, porém temia prejudicar a presença no culto. Querendo evitar as desavenças geradas nas distribuições anteriores, ela decidiu anotar o nome dos homens adultos, responsáveis pelas casas que visitava. Chamá-los-ia individualmente ao final da atividade evangélica para lhes entregar os presentes. Para isto, precisava tomar conhecimento das famílias dos mais de 700 habitantes da aldeia em poucas horas.

Durante a tarde, os funcionários do Exército e os pregadores ligaram as caixas de som em frente à escola, preenchendo a aldeia com música gospel, e dispuseram as carteiras escolares voltadas para onde deveria estar o púlpito, espaço que eles ocupavam. Microfones em punho, convocaram os Apanjekra ao culto. As crianças se aglomeraram para ver o que aconteceria; os kupen lhes prometiam lanches após a pregação. Os jovens que compareceram observavam a distância e os adultos ficavam atrás das carteiras, onde seus filhos estavam sentados, em frente ao pastor. Apesar daqueles com idade inferior a 7 anos não dominarem o português, eram essas crianças que estavam no centro do culto.

De qualquer ponto de Porquinhos se ouvia os evangelizadores. Diversas músicas foram tocadas a partir de gravações e o cantor gospel entoou outras tantas. O major deu seu testemunho de fé e foi às lágrimas, agradecendo a Deus pela oportunidade de estar ali levando a Palavra aos índios. O pastor chamou as principais lideranças indígenas para irem até onde estava e permanecerem ao seu lado durante o culto. ${ }^{12}$ Como o cacique não estava presente no início da pregação, o vice-cacique ficou junto aos missionários, exortado a responder se já havia aceitado Jesus (retórica, a pergunta permaneceu sem resposta) e a traduzir as passagens mais marcantes para os nativos. A pregação afirmava haver apenas um Deus, o "pai maior", e que a salvação era exclusiva daqueles que o aceitassem. A secretária de Maria, 
sentada na primeira fila junto às crianças, chorava emocionada. Observava as crianças, que se animavam sempre que o vice-cacique transmitia um trecho da fala do pastor na língua timbira.

Rapidamente, a fala do tradutor se dissociou do discurso do evangelizador. Após duas tentativas de explicar o que era pregado, tratando da vida após a morte, da eternidade no céu e da aceitação de Deus, o vice-cacique decidiu ignorar o que era dito em português. Escolhia livremente suas frases, tentando incutir nas crianças o comportamento adequado à situação, de acordo com a expectativa dos kupen. Falar na língua timbira sobre salvação e pecado era uma tarefa hercúlea, pois estes termos não têm um correspondente direto no vocabulário indígena e são conceitos cristãos desconhecidos dos Apanjekra. A complicação era ainda maior pelas crianças serem o foco das atenções: quando o tradutor tentou reproduzir fielmente o que o pastor falava, ao invés de as crianças expressarem a comoção ansiada pela comitiva gospel, demonstraram espanto e incompreensão.

Falar para as crianças que os mortos deviam ir para o céu, onde viveriam eternamente, colocava um desafio semelhante. A noção de post-mortem dos Apanjekra difere daquela apresentada pelo cristianismo: a morte é concebida como um processo transformador, em que o falecido passa a existir sob uma forma distinta. O duplo da pessoa (seu karon, traduzido como espírito ou alma) deixa o corpo inerte e assume outro, abandonando também seus parentes e adquirindo novos em outra aldeia (Carneiro da Cunha 1978). Esta nova forma pode ser a de um animal ou a de uma sombra, ainda sem corpo. Uma pessoa que ao morrer se torna um porco viverá na aldeia dos porcos (com uma organização social semelhante à dos Timbira) e terá seus parentes porcos. Ela os verá como humanos, ao passo que os Apanjekra serão vistos por ela como animais. ${ }^{13}$ Morrer implica uma mudança no registro do parentesco e da humanidade, nos termos do perspectivismo ameríndio definido por Viveiros de Castro (1996). É aí que se concentra a alteridade funerária timbira, extensamente desenvolvida por Carneiro da Cunha para os Krahô (1978). Na escatologia apanjekra inexiste qualquer ideia de deslocamento ao céu ou a alguma forma de Paraíso. Também é estranha a noção de "eternidade", posto que nenhum estado da pessoa é permanente - tanto a humanidade quanto o parentesco precisam ser produzidos, processualmente (Coelho de Souza 2002, 2004).

Em êxtase durante o momento de louvor, os forasteiros não perceberam a complicada tarefa que o tradutor enfrentava, tampouco a solução adotada por ele. Na noite daquele dia, Maria me disse confiar na mensagem passada aos índios em razão da universalidade da Palavra. Como prova de seu sucesso, mencionava a comoção de seu público. Os membros da comitiva mediam o 
evento a partir da animação das crianças, especialmente no momento em que o pastor perguntava se elas aceitariam Jesus. Porém, para contornar o abismo de entendimento que existia entre as proposições evangélicas e o universo infantil, o vice-cacique conduziu meninas e meninos por outro caminho: quando o pastor perguntava quais das crianças estavam em um culto pela primeira vez, o tradutor pedia que apenas a primeira fila levantasse a mão; para responder quem comparecera aos cultos realizados meses antes, os demais foram solicitados a se manifestar; se questionados a respeito de quem gostava de Jesus, exortava todas as crianças a gritar "Jesus, Jesus!". A comitiva evangélica se emocionava, sem perceber o que se passava.

Havia ali um duplo evento, em que o público mirim participava de uma gincana, divertindo-se à espera de presentes e lanches, ao passo que os pentecostais habitavam um ambiente de louvor. A secretária fotografava as crianças respondendo na língua timbira ao tradutor que sim, queriam comer biscoitos, após o pastor interrogar: "quem ama e aceita Jesus?". A maioria dos Apanjekra adultos se ausentou ao longo do culto, e o vice-cacique mediava a situação destoante vivida pelos dois grupos, de acordo com os interesses percebidos de cada um. Os indígenas bilíngues compreendiam o que ocorria, observando de uma posição similar àquela ocupada pelo tradutor, que operacionalizava o "equívoco descontrolado" do pastor (Viveiros de Castro 2004). Não havia motivo para interferirem. Conquanto os adultos se mostrassem reticentes em atender aos chamados para subirem ao palco, as crianças eram facilmente levadas a fazê-lo, divertindo-se com as ordens dadas pela liderança ("todo mundo corre para o palco!"; "Quando o kupen falar Jesus, é para repetir!").

A pregação teve três momentos principais: no primeiro, Maria e os oficiais do Exército deram testemunhos autobiográficos, narrando momentos em que a fé foi determinante para superarem uma dificuldade. No segundo momento, os pastores tomaram a palavra, falando da necessidade de se aceitar Jesus, tema central do culto. Era preciso amar e receber o amor de Jesus, sob o risco de se trocar o Paraíso pelo Inferno. Perguntavam se a plateia aceitava Jesus e eram respondidos pelas crianças. Na parte final, explicaram que a congregação religiosa de que faziam parte promovera uma campanha de arrecadação de cestas básicas e roupas para os indígenas. Mobilizaram muitas pessoas para "ajudar" a comunidade e distribuiriam os presentes que os evangélicos davam para a aldeia Porquinhos. Durante a primeira parte do evento, a necessidade do tradutor era pequena, pois havia muitos adultos presentes. Foi a partir da segunda etapa do culto, quando boa parte dos adultos se afastou do evento e as crianças se tornaram o centro das atenções, que o vice-cacique passou a "traduzir" o que o missionário dizia. 
Esse processo, é claro, tinha boa dose de humor. Havia duas piadas. A primeira, sobre as traduções quase impossíveis, por questões semânticas (como traduzir "Paraíso" ou "Inferno"?) e contextuais (qual o sentido que isso teria para aquelas crianças?). O vice-cacique e os demais Apanjekra adultos presentes riam da própria situação em que se encontravam. E havia também o riso de saberem o que estava acontecendo por dominarem as duas línguas e manipularem a situação, à revelia das crianças (que riam das brincadeiras) e dos missionários (que não riam, mas estavam contentes com o sucesso do evento). As relações jocosas possuem destaque na dinâmica social timbira, indicando proximidade e companheirismo, por contraste às relações de evitação estabelecidas com os amigos formais (hopin' e pinxoj, amigo e amiga formal, respectivamente). Não eram essas relações que se estabeleciam entre os Apanjekra e os evangélicos: o riso era exclusivo de um lado da relação.

O cacique apareceu no fim da pregação. Convidado pelos kupen, participou da entrega de cestas básicas, na conclusão do culto. Maria e o pastor anunciavam o nome de um homem, que deveria se dirigir até o palco e retirar a doação. Os problemas surgiram rapidamente: muitos homens não estavam presentes, estando em seu lugar suas esposas ou mães. Os aldeões foram informados que a comitiva distribuiria alimentos depois do culto. Como a gestão do alimento doméstico é feita pelas mulheres, foram estas, e não os homens, que buscaram as doações. Havia outros complicadores: em uma população com padrão de residência uxorilocal como os Timbira, a casa está diretamente ligada à mulher adulta (que corresponde à "mãe" dos habitantes nascidos na residência), que nela permanece ao longo de sua vida. O homem, por sua vez, se muda da casa de seus pais para a de sua esposa quando do matrimônio, e pode abandonar sua nova residência em caso de desentendimento com a esposa. Neste caso, ele retorna à moradia natal e, ao se casar novamente, segue para outra casa. A consequência é que mães solteiras, cujos ex-maridos tinham outras famílias naquele momento, não receberiam as cestas alimentícias, posto que apenas os homens foram "cadastrados" por Maria. Ao se chegar ao fim das doações, pelo menos uma dezena de famílias não fora mencionada.

Conquanto algumas pessoas não tivessem se incomodado em não receber as cestas básicas, as mães solteiras expressaram grande descontentamento. São elas que, na percepção nativa, mais necessitam de dádivas, tendo maior dificuldade em obter carne de caça ou pesca (atribuição masculina) e em se relacionar com os kupen para adquirir os bens produzidos por eles (o contato com os não indígenas é conduzido quase sempre pelos homens, que têm maior domínio do português e alguma proficiência no sistema de contagem ocidental, facilitando o acesso a benefícios sociais e o trato com o dinheiro). 
A apoteose da visita de Maria a Porquinhos, do ponto de vista de sua comitiva, foi o culto evangélico e a conversão dos jovens. A grande emoção que estampavam em seus rostos ao verem cerca de 40 crianças e outros tantos adultos recebendo a Palavra do Senhor não deixava dúvidas quanto a isto. Após a doação de alimentos às famílias e de lanches (sucos em pó e biscoitos industrializados) às crianças, os kupen deixaram o convívio junto aos mehin, recolhendo-se às instalações do Posto de Saúde e demais construções feitas pelo Estado. A entrega das roupas sequer foi feita presencialmente. Em virtude dos problemas de distribuição das cestas básicas, Maria decidiu passar essa incumbência ao pahí, para que este promovesse o melhor arranjo. O grupo de evangelizadores não estava presente quando, na manhã do dia seguinte, as roupas foram divididas no pátio central. Os problemas pós-culto e a sensação de "dever cumprido" contribuíram para esta ausência. Eu os visitei algumas horas após a pregação, quando discutiam se já deixariam a aldeia ainda naquela noite ou se ficariam até a manhã seguinte. Optaram pela última opção pela péssima condição da estrada de lama e areia que precisaria ser percorrida por vários quilômetros até se chegar à rodovia.

Os Apanjekra vivenciaram um evento radicalmente diferente daquele pretendido pelos pentecostais: o culto não foi compreendido pelas crianças, alvo da atuação evangélica, e poucos adultos o acompanharam por completo. Para os indígenas, o momento mais importante foi o compartilhamento de dádivas que, secundário aos olhos dos kupen, foi um desastre. Além dos problemas da distribuição das cestas básicas e da ausência de Maria e seus acompanhantes na entrega das roupas, os Apanjekra criticaram a baixa qualidade das doações recebidas. Havia alimentos vencidos que foram descartados. Minha irmã e algumas mulheres vizinhas à minha residência encontraram vermes no arroz e nos biscoitos das cestas básicas, optando por se desfazerem também dos demais itens. No dia seguinte, com a comitiva deixando Porquinhos logo antes da distribuição do vestuário no centro do pátio, os homens avaliaram os presentes recebidos livremente. As roupas foram levadas para o centro da aldeia e expostas para todos os homens adultos que ali se perfilavam para distribuírem as peças entre si. Retiradas dos sacos, foram imediatamente consideradas iguais ou piores que as roupas que os Apanjekra já possuíam, por serem velhas e sujas. A quantidade de camisas e bermudas entregues pelos evangélicos sequer foi discutida, já que várias pessoas não quiseram receber as peças que lhes cabiam. Ao escutar o que aconteceu no pátio, minha irmã, que descartara a cesta básica na noite anterior, disse: "Maria e os amigos dela não são do povo de Deus". 


\section{Povo de Deus, cristianismo analógico}

Diversas mulheres fizeram críticas semelhantes às de minha irmã ao longo daquele dia. Se os Apanjekra têm um valor moral primário, este é a generosidade. A generosidade está na base da vida social indígena, é a manifestação mais clara do parentesco e a principal qualidade que uma pessoa precisa ter para ser considerada para quaisquer cargos "de liderança" (pahís e governadores) na aldeia. Crocker (1990:87-88, 184, 213) escreveu que, para os Canela, a pior característica possível para uma pessoa é a sovinice. O compartilhamento é uma imposição moral, que estabelece que aqueles que têm determinados privilégios os dividam com os demais. Por privilégio entendo aqui tanto a abundância alimentar como o acesso a certos bens que nem todos os aldeões obtêm. Trata-se, portanto, de aspectos quantitativos e qualitativos: grandes caçadores acabam cedendo mais comida aos seus parentes do que os pequenos caçadores; famílias que recebem mais recursos do Estado (por contarem com algum funcionário público ou aposentado em sua composição), conseguindo mais objetos dos kupen, são solicitadas pelas famílias menos favorecidas a suprir necessidades cotidianas, cedendo fumo, pilhas e anzóis, além de precisarem contribuir com maiores valores para a compra de gado pela aldeia durante os rituais.

Já foi notado por diversos autores como o compartilhamento não corresponde à noção de "reciprocidade generalizada" cunhada por Sahlins (1972), por não haver exigência no pagamento futuro da dádiva recebida: conquanto as posições de doador e receptor ainda existam, o favor não implica endividamento, sendo antes uma obrigação moral de quem cede e um direito de quem ganha (Woodburn 1998; Widlock 2013). Além disso, o compartilhamento não está limitado ao ambiente doméstico, ao contrário da reciprocidade generalizada (Sahlins 1972:199). Por ser o comportamento esperado, o ato generoso é menos marcado do que o mesquinho, que causa uma ruptura na expectativa de uma relação comunal. A acumulação de bens é um índice negativo da pessoa: é aqui que se encontra o caráter coercitivo da dádiva, não na ausência de retorno, e sim na prática do acúmulo. Os poucos indígenas que, através de diferentes arranjos com os kupen da região, conseguiram atingir uma riqueza material para os padrões locais, foram instigados a dissolvê-la em suas redes de relações. Ser sovina, nesses casos, é negar uma relação e tem como resultado a marginalização do acumulador, que se torna alvo de comentários pejorativos e deixa de ser considerado um bom parente, companheiro ou potencial líder político. ${ }^{14}$

Por isso, a opinião nativa sobre a comitiva de Maria era indissociável da forma com que as dádivas aconteceriam. Tendo acesso a recursos e a 
bens desejados pelos mehin, os kupen são vistos como grandes doadores potenciais. Os Apanjekra se veem no direito de usufruir das «invenções dos kupen" (ver Crocker 1990:184), itens exclusivos dos brancos que os indígenas não conseguem produzir (como eletrodomésticos, roupas e alimentos industrializados). A recíproca é verdadeira, dizem os indígenas, pois originalmente foram eles que descobriram o fogo e as plantas cultiváveis, hoje também utilizados pelos brancos. Além disso, os estrangeiros que vão a Porquinhos são adotados, recebem nomes, abrigo e comida. Os Apanjekra não esperam ou exigem pagamento por sua hospitalidade. Eles a justificam dizendo que, se não acolhessem bem, os visitantes não teriam onde dormir, passariam fome e ficariam ao relento, adoecendo - por isto, devem ajudar, mesmo aquelas pessoas que nunca mais retornarão para retribuir a seus anfitriões. O problema ocorre na cidade, onde os kupen teriam condições de ser generosos, mas não permitem que os indígenas acessem gratuitamente suas mercadorias. Idealmente, os Apanjekra deveriam poder pegar os objetos desejados, como fazem com a própria produção aldeã (o termo utilizado para "pegar" uma coisa, seja na horta ou no mercado, é o mesmo: gapa; quando querem destacar que precisam pagar por algo, usam o verbo "comprar", em português). É essa sensação de direito aos bens que desejam e que os kupen têm em abundância que lhes permite pedir, exaustivamente, como notado por outros antropólogos (Crocker 1990). O evento a que assistiram os nativos de Porquinhos teve sua apoteose depois daquela vivenciada pelos evangélicos e, se este grupo avaliou positivamente o evento a partir das manifestações infantis, os mehin certamente ficaram frustrados. A má distribuição de cestas básicas e roupas, junto ao péssimo estado das dádivas, tornou o grupo de Maria não apenas malvisto como também levou várias pessoas a questionarem se, de fato, pertenciam ao Pahpam gateje, "povo de Deus". ${ }^{15}$

Conquanto a tradução de gateje para o português (nesse contexto, "povo") não levante objeções, há uma ambiguidade no termo encontrado pelos missionários do SIL, na década de 1970, para denotar a divindade no Timbira Oriental: Pahpam é uma construção que toma como base uma relação de parentesco. Pam significa "pai", enquanto pah é um superlativo: Pahpam é o "pai grande", e muitos kupen ignoram este significado. Tal desconhecimento leva os forasteiros a reduzir o conteúdo semântico do termo a "Deus". Este equívoco é exacerbado quando, ao chegar na aldeia, os pregadores são chamados de "povo de Deus", estando ali para "contar histórias de Pahpam".

Os missionários hodiernos reclamam da baixa receptividade encontrada junto aos Apanjekra. Gerson, um jovem pastor da Missão Evangélica aos Índios do Brasil, residente em Barra do Corda, me relatou a dificuldade em 
estabelecer relações positivas e duradouras com os mehin, uma vez que estes "só estão interessados nos presentes e não entendem que não temos dinheiro para comprar muita coisa". Ele me disse que, exceção à família do único indígena a sempre se declarar "crente" em Porquinhos, os demais Apanjekra não estudavam a Bíblia, não tinham interesse pelos cultos (que raramente são realizados na aldeia, nunca promovido pelos próprios habitantes) e insistiam que os missionários lhes dessem gado para ser abatido e distribuído pelos moradores da aldeia. Como a Missão era sustentada por doações, explicou, não tinham recursos para atender às demandas indígenas, bancar os custos do transporte para a aldeia e ainda viverem na cidade: "os Canela têm uma visão dos missionários do passado, que tinham dinheiro e queriam agradar os índios com presentes. Somos pobres, tentamos passar isso para eles, mas acham que é mentira, que estamos escondendo o que temos".

A figura de Pahpam, da forma com que surgiu no encontro dos missionários com os indígenas, estabelece uma analogia com um elemento estrutural do parentesco nativo. Ao contrário do que se vê em outras traduções do termo "Deus", para os Apanjekra, a palavra não remete a uma propriedade específica da entidade. ${ }^{16}$ Como foi dito, a generosidade é o conteúdo primário do parentesco, mas ela não se manifesta da mesma forma em todas as relações. Seguindo Wagner (1977), se a solicitude é matéria-prima dos laços de parentesco, é função humana diferenciar essas relações. Como se sabe, o parentesco nas Terras Baixas da América do Sul se centra na produção corporal e afetiva da pessoa e das relações que a compõem (Overing 1977; Seeger, Matta \& Viveiros de Castro 1979; Vilaça 2002, 2005; Viveiros de Castro 2002c), ponto que também é válido para os Jê (Coelho de Souza 2002, 2004; Ewart 2005, 2014; Lea 2012, dentre outros). É, então, no corpo que essa diferenciação será realizada.

Entre os mehin, os homens adultos são responsáveis pelo provimento da residência. Como um pêndulo, eles alternam entre o domínio interno da casa e o externo da aldeia, indo buscar alimento e retornando com a caça. Esta é entregue à esposa para preparo da refeição e distribuição desta entre os familiares. A captura de elementos no exterior é função do homem e extrapola o domínio da predação literal. Também as lideranças, em especial o pahí e seu vice, realizam viagens a fim de obter vantagens para a aldeia, seja visitando outros povos timbira, seja indo para as cidades negociar com os kupen (governo, comerciantes, criadores de gado).

O chefe cumpre, em outra escala, uma função análoga à do caçador. Se este retorna à sua residência com um animal que poderá alimentar seus parentes por um ou mais dias, o chefe busca abastecer a aldeia inteira, trazendo bois para serem esquartejados e divididos entre todas as casas. E, assim 
como o homem adulto deve conseguir outras coisas que não apenas comida para a casa (como miçangas, fumo, roupas e outros itens industrializados dos brancos), o chefe, em sua condição de diplomata, o faz em benefício de todos os habitantes. Essas figuras masculinas operam como mediadores entre um interior (a casa, a aldeia) e seus exteriores (a mata, a chapada, a cidade), provendo o primeiro com elementos do segundo. Assumem uma forma magnificada (Fausto 2008), capaz de representar e operar a partir de um ambiente em outro, e não é privilégio dos humanos: há também o pahí dos porcos, dos jabutis, das antas e de tantos outros animais. É com eles que caçadores e xamãs costumam negociar durante suas atividades, evitando infortúnios e vinganças dos chefes das outras espécies sobre a aldeia.

Para realizar essas atividades, o corpo de um mediador precisa ser desenvolvido. Ele precisa ser forte para poder suportar a incursão por diferentes domínios, não caindo vítima de ataques de animais ou espíritos na floresta, aguentando a fome na cidade, permanecendo fora de casa por longos períodos e dispensando tratamento médico constante. Apenas após completar os principais rituais de iniciação é que uma pessoa se torna um bom caçador: ela passa a ter um corpo firme, ágil e limpo. Mas um bom corpo não basta para se tornar um bom mediador: é também necessário ser generoso e saber em benefício de qual domínio se deve atuar. Um chefe precisa buscar o melhor para toda a aldeia e não apenas para si, bem como um caçador deve distribuir sua presa entre os demais membros de sua família extensa e amigos formais, para além de seu núcleo familiar. Quando as pessoas não atendem a estas expectativas, os prejudicados afirmam que o sovina "não pensa na gente" ou "nos escuta, mas não nos entende". A mesquinharia está fundada na ausência de um fundo comum de intersubjetividade (Ewart 2005:14-15; 2014:176-179), que leva à indisposição social.

A noção de mediador está intimamente ligada, porém não limitada, à paternidade, de modo que esta é um símbolo daquela. Um pai é um homem adulto, que passou pelos rituais de iniciação e gerou outro ser humano junto com sua esposa. Ele tanto possui um corpo maduro como é base para a humanidade (e, portanto, ponto de vista) de alguém, a quem seu corpo influencia. A metáfora do mediador também é assumida por Deus. Como "pai grande", ele é descrito no encontro entre os indígenas e os missionários como um poderoso provedor que deve cuidar dos seus.

É difícil precisar quando os Apanjekra começaram a contar a «história de Pahpam": não há registro de sua existência no material de Nimuendajú ou de William Crocker, os dois principais etnólogos a coletarem dados antes da chegada dos missionários evangélicos nas aldeias canela. Por isso, é difícil definir se este personagem mítico existia antes do contato com o cristianismo 
ou se é fruto da interação com os pregadores. Apenas algumas das pessoas entrevistadas por mim disseram ter ouvido as "histórias de Pahpam" de seus pais ou avós, quando eram crianças e, mesmo nestes casos, as "histórias" não eram as narrativas mais transmitidas de uma geração para outra. Ao contrário de outras peças da mitologia apanjekra, como os mitos de origem do fogo, dos cantos, do ritual do Pep Kahàk e dos kupen, a "história de Pahpam" apresenta significativas diferenças quando contada por narradores distintos. Este poderia ser um indício de sua recente adição à mitologia indígena. Porém, muitos de meus interlocutores me disseram que Pahpam sempre esteve olhando por eles, e que os antigos sabiam disso, o que favoreceria a ideia de que este personagem já existia quando os missionários passaram a falar de Deus.

No mito, Pahpam é um ser poderoso, que vive na terra com os humanos e os animais. Com Pahpam presente, todos os seres falam a mesma língua. Um caçador consegue se comunicar com sua presa, perguntando a ela onde se encontra. Ela não apenas responde, como aceita ser abatida. A narrativa é permeada por diálogos como este: "ei, tatu, onde você está? Eu estou com fome e quero te comer"... "eu estou no buraco, no pé de jenipapo, pode vir me pegar que minha carne está macia!". Há comida em abundância e não há conflito entre as pessoas ou as espécies, pois todos se entendem, e assim ninguém é enfeitiçado ou adoece. Um dia, Pahpam resolve dar uma festa. Ele pede ao macaco para ajudá-lo, indo aos membros de cada espécie para lhes pedir alguma coisa e convidando-os. Porém, a cada vez que o mensageiro visita um animal, ele altera a mensagem original, levando a Pahpam algo diferente do que este havia solicitado. Uma indisposição crescente se instaura entre Pahpam e os outros seres, que não cumprem o que o "pai grande" espera deles. A festa é um fiasco. Todos os animais brigam entre si e Pahpam, furioso, decide abandonar a terra e ir para o céu. Desde então os animais não se entendem mais, tornando as brigas comuns, a caça mais difícil e as doenças frequentes.

Apesar de seu nome, Pahpam não é pai biológico de nenhum personagem da história, nem criou os diferentes seres que habitam o universo. No mito, que reverbera os temas bíblicos da Queda e de Babel, o caráter excepcional de Pahpam está na criação de um fundo de mútua inteligibilidade entre os animais. ${ }^{17}$ Não apenas falam a mesma língua, como eles cooperam uns com os outros. O pai magnificado leva ao limite a função mediador-provedor, reduzindo o coeficiente de diferença entre as espécies de tal modo que a própria predação se torna um compartilhamento voluntário de si. Aos olhos de Pahpam, todos são parentes, e o ponto de vista estabelecido por ele abrange os demais. É só quando ele abandona o convívio terreno que a diferença é instaurada. 
Ser do "povo do Pai Grande", como os Apanjekra classificam os missionários, não implica pregar ou ter fé. A existência de Pahpam não está em questão, e o interesse pelas histórias bíblicas ou pelos cultos é baixo. A verdadeira manifestação de Pahpam está na generosidade, na capacidade de se compreenderem as necessidades do outro e conseguir saná-las, tal qual um grande chefe doméstico ou aldeão deve ser capaz de fazer. O potencial de ser um chefe-provedor que todo kupen apresenta, devido à sua facilidade em obter bens e serviços de difícil acesso aos indígenas, é exacerbado quando se trata dos missionários. Os companheiros de Maria frustraram não apenas as expectativas dos Apanjekra de receberem dádivas apropriadas, mas também falharam ao pernoitar e comer com os kupen na área externa da aldeia. Não se estabelecer na casa da família adotiva demonstra indisposição em compartilhar e se aparentar com os anfitriões. A identificação da comitiva como Pahpam gateje foi comprometida, assim como a de Maria como mehin.

\section{Generosidade e estabilidade}

O que os pastores tentam transmitir é uma experiência transcendental, fundada na noção de crença e salvação. Mas o que está em jogo, para os indígenas, é a participação mútua na vida uns dos outros. Onde os evangelizadores falam de religião, os Apanjekra falam de parentesco. A questão não é apenas de termos mal traduzidos. O fundamental é que, enquanto uma parte está apregoando Deus (a divindade e a salvação da alma), os mehin ouvem Pahpam (o personagem mítico e o parentesco estabelecido pelo compartilhamento). A escolha do vice-pahí de descartar o conteúdo do culto que não atendia às expectativas infantis de receber agrados do Pahpam gateje foi uma decisão consciente de controlar o equívoco ontológico e cosmológico presente naquele evento (Viveiros de Castro 2004): ele não apenas traduziu "Deus" por Pahpam, como também fez a correspondência das propriedades relacionais da divindade cristã para o contexto indígena. Se, à primeira vista, ele enganou os missionários, ele reafirmou a generosidade de Pahpam, prometendo alimentar as crianças ao fim da gincana. Além de ser muito desafiador expressar na língua timbira o que o pastor falava em português, o resultado seria uma mensagem que, para os Apanjekra, nada teria a ver com Deus.

Tentar fazer os Apanjekra acreditarem em algo cuja existência eles questionam explica parte do fracasso relativo dos missionários nos últimos anos. Além disso, assumir que a experiência cristã está fundada em uma ruptura com o modo de vida pagão (Robbins 2007) leva os evangelizadores 
a não reconhecerem os indígenas como convertidos, insistindo que eles aceitem Pahpam. Na segunda e última noite que passaram em Porquinhos, ouvi alguns membros da comitiva de Maria comentarem que, apesar de muitos índios terem participado do culto, eles também precisavam agir como cristãos. Ideia semelhante já me havia sido transmitida por um missionário residente em Barra do Corda: não basta se dizer evangélico, é preciso ter uma vida evangélica. Para além dos pastores, a população das cidades próximas a Porquinhos considera os indígenas pecadores. Funcionários do Polo de Saúde Indígena me disseram algumas vezes que a causa de muitas doenças de que tinham que tratar era a libertinagem aldeã. Esta afirmação não se limitava às doenças venéreas. A cura para os índios não seria remédio ou atendimento médico, mas a Bíblia e Jesus.

Os kupen distinguem os pagãos dos cristãos não apenas a partir da fé, mas também da conduta. Os Apanjekra classificam as pessoas em duas categorias: os "católicos" e os "crentes". A distinção nada tem a ver com questões cosmológicas ou de crença, baseando-se exclusivamente no comportamento. Por "crentes" eles entendem as pessoas que não ingerem bebidas alcoólicas, não fumam e tampouco têm relações extraconjugais. Já os "católicos" correspondem àqueles que não seguem o código dos crentes. Durante meu primeiro campo, presenciei um recém-chegado funcionário da Funai perguntar a um apanjekra se ele era crente. Ele lhe respondeu: "não está me vendo fumando? É claro que eu sou católico". Salvo raras exceções, a aldeia inteira se define como católica. Durante diversas incursões a Porquinhos entre 2011 e 2016, apenas uma família sempre se considerou e foi considerada crente pelos indígenas e pelos missionários.

Segundo meus interlocutores (apanjekra e alguns missionários), há décadas os clérigos católicos pararam de tentar converter os indígenas da região. Durante meu campo, apenas uma vez encontrei um padre na aldeia, acompanhando padres espanhóis que faziam turismo em Porquinhos. Chegaram de manhã e partiram antes de escurecer. Não celebraram missa ou pregaram, apenas fotografaram um ritual. Este padre me confirmou que suas atividades se concentravam nos centros urbanos e que sua congregação não atuava na aldeia. Fui também informado por um missionário pentecostal que os evangélicos se diferenciavam dos católicos por lutarem contra desvios morais dos índios. Quando pregavam na aldeia, indicavam como viver de acordo com a Bíblia.

O discurso dos evangélicos e o pouco contato recente com o catolicismo podem ser os motivos para os Apanjekra associarem os crentes às restrições de conduta. Mas por que os Apanjekra escolheram estas três interdições, dentre todas as postuladas pelos missionários, como as mais representativas 
do "ser crente"? O fumo, a bebida e a relação sexual constituem dispositivos de desestabilização corporal. Cada um, a seu modo, possibilita a transformação do corpo. Se a "socio-lógica" indígena está alicerçada em uma "fisio-lógica" (Seeger, Matta \& Viveiros de Castro 1979), uma alteração nos veículos de afecção corporal implica uma alteração na pessoa e em seus princípios relacionais.

O tabaco é amplamente empregado pelos xamãs em suas atividades, sendo necessário para que os curadores contatem os espíritos e restaurem a saúde dos doentes. Mas o fumo não se restringe ao tabaco: os Apanjekra plantam psicotrópicos, de grande valor medicinal, que também permitem a comunicação com espíritos. Toda possibilidade de alteração da consciência do fumante é condenada pelos pastores, da mesma forma com que criticam o sexo fora do matrimônio. Os Timbira costumam manter vários parceiros sexuais, mesmo após o casamento, distinguindo os esposos dos amantes (a quem chamam de "namorados"). Com os últimos, os relacionamentos ocorrem em situações excepcionais, como em determinados rituais ou durante a ausência prolongada de uma das partes do casal, devido a viagens. Como a prática sexual é uma das principais vias de compartilhamento de substância, podendo alterar tanto o corpo do homem quanto o da mulher (inclusive gerando uma nova pessoa), as relações extramaritais permitem que não corresidentes afetem a constituição da pessoa e participem de sua produção.

Mas o cerne das preocupações de missionários e indígenas está no álcool. O termo empregado pelos Apanjekra para definir a embriaguez é o mesmo para a loucura, e de um ébrio se diz tanto que está "bêbado" como "doido" (traduções para a mesma palavra, bipãni). Quem está bêbado "escuta diferente" ou "escuta, mas não entende": é como se quem está sóbrio falasse uma língua diferente daquela do embriagado. A perda do ponto de vista humano é destacada no comportamento: o bêbado pode se tornar "valente" (hobré), atacando seus próprios amigos e parentes, que não mais reconhece. Mesmo que a ingestão de alcoólicos seja central aos rituais, por estar associada à alteração de perspectivas inerente às festas (Stolze Lima 2005; Seeger 2015), os habitantes de Porquinhos passaram a discutir a presença dessas bebidas no cotidiano da aldeia. Nos últimos anos, o alcoolismo se tornou a maior causa de cismas familiares e separação de casais, de acordo com as lideranças indígenas.

Nos debates que presenciei sobre como lidar com o consumo excessivo de álcool, as principais soluções focavam nos kupen que levam as bebidas para a aldeia. Elas consistiam em: pedir que os motoristas que fazem o trajeto da cidade para a aldeia não transportassem alcoólicos; revistar carros 
para impedir a entrada de álcool; banir de Porquinhos os comerciantes kupen que vendessem bebidas na aldeia. Em todos estes casos, os Apanjekra consideravam impor sanções aos forasteiros. Porém, como parte da bebida é transportada pelos próprios indígenas, aos quais as lideranças não podem imputar nenhuma pena, "entrar para o crente" foi considerada uma alternativa. Uma liderança apresentou esta ideia no dia seguinte a uma briga entre duas irmãs embriagadas. A proposta, feita no final de 2012, era que os chefes da aldeia passassem em cada casa, aconselhando as pessoas a pararem de beber, para não acabarem com suas famílias e se envergonharem. Aqueles que não conseguissem limitar o consumo de aguardente poderiam procurar os evangélicos, porque eles não bebiam e ajudariam os necessitados a evitar a bebida.

Não estava em questão uma conversão coletiva ou mesmo uma grande adesão aos preceitos propagados pelos missionários, e sim uma estratégia de combate aos conflitos internos à aldeia. Buscar a ajuda dos religiosos seria uma escolha pessoal e pragmática. Neste mesmo ano, o anterior ao culto organizado por Maria, reencontrei Patrício, que em 2011 era marido de uma de minhas irmãs adotivas. Este meu antigo cunhado indígena me explicou sua decisão de "entrar para o crente". Sua esposa o expulsara de casa, pois Patrício bebia muito, arrumando confusão com a família dela. Envergonhado, ele reconheceu que ela estava correta, mas não conseguia se livrar do álcool para ser novamente aceito pela mulher. Iria então conversar com José, o único apanjekra evangélico da aldeia, para abandonar a bebida. Nos três meses de 2012 em que estive em Porquinhos, diversas pessoas me instruíram a evitar o contato com Patrício, já que ele poderia estar "valente" e não me reconhecer. Estigmatizado nas reuniões no pátio central e proibido de frequentar a casa em que eu residia, só o revi no ano seguinte.

Dessa vez, Patrício estava de volta à casa que eu habitava. Quando o questionei sobre o ingresso "no crente", ele me disse que não precisava mais. Já havia largado a bebida e reatado com minha irmã. Contou que conversou com José e descobriu que, para ser crente, não bastava evitar o álcool: ele também não poderia fumar ou ter namoradas. Preferiu continuar católico e abandonar o álcool por conta própria. Mesmo aqueles que escolhem "entrar pro crente" raramente permanecem evangélicos por muito tempo: quando as grandes festas acontecem, quase todas as pessoas ignoram as interdições e não voltam atrás.

Os códigos de comportamento impostos aos crentes restringem relações e processos de transformação da pessoa, bloqueando afecções corporais. Caminham rumo à estabilização do indivíduo, estando em conflito com as práticas de rituais e do xamanismo, duas das principais vias de alteração 
nativa a partir do contato com os espíritos e os animais que vivem fora da aldeia. Mas nem toda instabilidade é negativa: para crescer, se fortalecer e permanecer saudável, é necessário transformar o corpo. A humanidade e o parentesco, para os Timbira, não são dados, pertencendo antes à ordem do construído (Coelho de Souza 2001, 2002, 2004). Os grandes rituais são indispensáveis ao bem viver; são momentos de renovação das propriedades fisiológicas, em que os jovens se moldam adultos, adquirindo as habilidades necessárias para caçar, correr com toras, curar ou cantar. Uma pessoa que não participa das festas fica velha (-tum), fraca (-pec) e sua cabeça divaga, estando à mercê de moléstias e demonstrando dificuldades para trabalhar. E tanto "crentes" quanto "católicos" podem ser vitimados por doenças e espíritos danosos, precisando recorrer ao xamanismo para recuperar a saúde.

Seja nos rituais, seja no cotidiano, a produção da humanidade e do parentesco toma como matéria-prima aquilo que existe no exterior do grupo. É apenas o que está do lado de fora da identidade que pode ser incorporado no "vetor de consaguinização" (Viveiros de Castro 2002c:455), ponto bem desenvolvido para a Amazônia (2002c) e para o Brasil Central (Coelho de Souza 2004:48-ss). E não há como atuar apenas em uma direção: para se apropriar de um elemento externo, é necessário sair de si. Como colocou Viveiros de Castro, "o exterior é imanente ao interior" (2002c:430). Entre os Apanjekra, a renovação ritual ocorre a partir de práticas aprendidas com espíritos e animais em tempos imemoriais; a comensalidade diária tem em sua base a substância de outras espécies que, abatidas no exterior da aldeia, serão preparadas para consumo em seu interior. Seja nos mitos de aprendizado das festas ou na caça hodierna, há uma jornada em que alguém sai do convívio dos seus para ingressar em território estrangeiro, e então retornar. Esta também é a lógica das viagens às cidades para aquisição dos produtos dos brancos (com o dinheiro dos benefícios sociais) e da atividade do xamã.

Se a instabilidade total leva à captura do sujeito por outras agências, deixando de perceber seus semelhantes como parentes (portanto, abandonando a humanidade compartilhada), permanecer sempre o mesmo implica o fim do processo de produção da pessoa que, no limite, leva à mesma transformação: a morte. E esta se apresenta tanto na pessoa enfraquecida (por não se alimentar) como em quem se volta apenas para si próprio, resultando no incesto (Coelho de Souza 2001, 2004), um "fluxo de similaridade moralmente indesejável" (Wagner 1977:624). O excesso dos evangélicos está na manutenção do pêndulo da pessoa no polo da estabilidade, enfatizando o processo de assemelhamento ao mesmo tempo em que busca minorar o da diferença.

Acima, mencionei que o pastor Gerson reclamava da dificuldade em superar as práticas das gerações anteriores de missionários, que sempre 
entregavam presentes no pátio para serem distribuídos aos Apanjekra. Estes eventos reforçaram a imagem de grandes doadores do Pahpam gateje: a obrigação moral imposta ao "povo de Deus" era cumprida, em consonância com o princípio da generosidade. Os evangelizadores atuais são vistos como mesquinhos. A percepção de uma ênfase no indivíduo ocorre não apenas no eixo corporal aqui tratado, mas também na ausência de dádivas e na perspectiva de acúmulo material que isto implica, criando pessoas sovinas. José, único habitante de Porquinhos que estuda para se tornar pastor, foi também o primeiro apanjekra a construir uma cerca ao redor de sua residência.

\section{Moralidades conflitantes}

Na etnologia americanista, a discussão sobre moral foi oposta às vertentes "racionalistas", que ignorariam o cotidiano da vida dos povos indígenas, deixando de lado seus sentimentos e afetos (ver Overing 1985; Overing \& Passes 2000). Buscando se afastar dos esquemas lógicos influenciados pelo estruturalismo, os maiores proponentes de uma "economia moral da intimidade" (Viveiros de Castro 2002b) não limitaram suas pesquisas aos domínios "masculinos" ou "políticos", centrais nas etnografias clássicas da Amazônia. Observaram também os espaços domésticos e a dinâmica comunitária, descrevendo o universo indígena a partir da experiência cotidiana. Junto a esta mudança de foco, Overing e Passes (2000) propuseram que outro ponto importante deveria ser considerado para pensarmos a moral e a estética indígenas: o "paradoxo" [sic] subjacente à formulação do "bem-viver" ameríndio e às instabilidades do cosmos, posto que as fontes para uma boa vida frequentemente advêm de um exterior perigoso, que precisa ser confrontado e domado para que o interior possa existir $(: 6) .^{18}$

Embora estas lições tenham levado a avanços em diversas áreas da etnologia, não vejo concorrência entre modelos "racionalistas" e o estudo da moral. Se o cerne do "bem-viver" está nas práticas de compartilhamento, comensalidade, corresidência e outros elementos da vida cotidiana, isto não significa que a sociologia nativa encontre aí seu limite. Como apontou Viveiros de Castro (2002c), há um fundo relacional que engloba o descompasso entre o ideal de assemelhamento da vida aldeã e os riscos desestabilizadores do mundo exterior. O "bem-viver" seria uma marca sobre o que é o dado dos povos amazônicos: a afinidade ou a predação, que resumem uma forma primária do princípio de circulação de pessoas nas terras baixas. Restringir nossa análise da ética indígena às condutas positivadas implicaria perder de vista outros aspectos necessários para a constituição da 
pessoa e do social. É preciso ter em vista que há uma "substância ética" a ser trabalhada a partir do código moral, e que este exercício será fruto de autorreflexão a partir do ideal de bem-viver a ser alcançado (Foucault 1984; Faubion 2009:3-4).

Para os Apanjekra, é o corpo que constitui a substância ética. A generosidade é concebida a partir da incorporação compartilhada de elementos estrangeiros pelos coletivos. Esta é a base do parentesco que almejam atingir: a mutualidade de uma transformação a partir da ingestão, tangível ou intangível, da diferença. Ser alterado por aquilo que (ainda) não o compõe, seja um animal, seja um cunhado, é o que produz novas pessoas. A questão, portanto, não se limita a um interior necessariamente positivo contra um exterior inevitavelmente negativo. Antes o que está em jogo é a boa medida, trabalhada nos mitos, no parentesco e central para as formulações morais indígenas (Lévi-Strauss 2006).

Como se argumentou, tornar-se "crente" não significa adotar uma fé, e sim seguir um código de estabilização da pessoa, rompendo parcialmente com a alteridade. Esta parcialidade está na ambiguidade da figura de Pahpam. O personagem mítico que missionários e indígenas equivalem a Deus é tanto aquele que permite um universo de entendimento mútuo como quem torna a caça mais abundante. A diferença entre os seres é mantida (existem, portanto, as posições de presa e de predador), mas a comunicação e a intersubjetividade (Ewart 2005) são possíveis. A humanidade comum que Pahpam produz entre os seres é paradoxal, pois os animais se compreendem mesmo sob formas diferentes. É aí que poderia estar, realmente, o "paradoxo do cosmos" mencionado por Overing e Passes (2000): subsumidos na perspectiva de Pahpam, os seres são humanos e animais ao mesmo tempo, e transitam livremente nos territórios uns dos outros.

A expectativa dos Apanjekra é que o "povo de Deus" encarne esta ambiguidade, sendo extremamente generoso com estranhos, mas sem se aparentarem: tornar-se mehin implicaria perder a capacidade de trazer presentes dos kupen. A passagem de Maria por Porquinhos destaca os tropos envolvidos na relação com o cristianismo e, em especial, com os pregadores protestantes que frequentaram a aldeia nos últimos anos. No passado, os evangelizadores se aproximavam através de doações, atendendo ao ideal de compartilhamento. Maria e os demais missionários contemporâneos, contudo, colocam a ênfase no culto, em detrimento das dádivas. Pregam sob o signo da generosidade, mas assumem um comportamento mesquinho.

Ainda que isto gere um problema ético para os missionários, os Apanjekra não descartam a possibilidade de "entrar para o crente". Apesar de protestantes e indígenas divergirem quanto à "substância ética" que deve 
ser trabalhada (para os primeiros, a alma; para os últimos, o corpo), aos modos de subjetivação e à finalidade do exercício ético, isto não significa que o código moral não interesse aos Apanjekra. A inovação dos pastores evangélicos contemporâneos é a insistência nas interdições corporais. Se a mesquinharia contraria a mensagem de Pahpam, o bloqueio das afecções fisiológicas é positivo nos contextos de grande desestabilização da pessoa, em que a humanidade e o parentesco são ameaçados. Suspender os veículos de maior afecção corporal permite à pessoa retornar ao ponto em que a compreensão mútua com os corresidentes é viável.

A chegada de Maria a Porquinhos e as mudanças no comportamento dos missionários não ocorrem descoladas de seu período histórico: a cada ano, o ingresso de álcool na aldeia aumenta, bem como aumentam as viagens para Barra do Corda por conta dos benefícios sociais. Na cidade, ocupam um barracão abandonado onde estendem suas redes e esteiras. Faltam paredes, esgoto, comida e água. Tudo deve ser comprado. Presos na cidade, aguardando as caminhonetes dos agiotas que levarão a Porquinhos os Apanjekra que pagarem pelo transporte, o dinheiro dos benefícios sociais pode acabar, gerando um quadro de fome e ansiedade. Neste cenário, o alcoolismo floresce.

Retornamos, portanto, ao tema da boa medida. Com as expectativas frustradas sobre o comportamento do "povo de Deus", os Apanjekra ainda retêm uma outra via de produção do parentesco a partir do código missionário. Uma via oposta, mas que pode levar ao mesmo objetivo: ao invés de tornar-se humano através do compartilhamento das práticas de alteração de si, as interdições corporais podem evitar tornar-se um outro não humano. Se não produzem diretamente o parentesco, razão pela qual são abandonadas nos períodos rituais, as interdições o mantêm, limitando os veículos de desestabilização ao mínimo aceitável.

Recebido em 04 de abril de 2018

Aprovado em 22 de junho de 2018

Bruno Nogueira Guimarães é doutor em Antropologia Social e pós-doutorando em Epidemiologia em Saúde Coletiva (ENSP - Fiocruz). Desenvolve pesquisas com povos indígenas, em especial os Canela Apanjekra, estudando políticas públicas, economia, parentesco e cosmologia. Atualmente investiga a relação do Estado com populações tradicionais através das políticas de saúde e de transferência de renda, com ênfase no modo como os povos indígenas são identificados e quantificados nas estatísticas oficiais. E-mail: brunongbh@gmail.com 


\section{Notas}

1 Ao utilizar o termo "Canela", estarei me referindo aos povos Apanjekra e Ramkokamekra, sem maiores distinções; por suas aldeias serem próximas, falarem a língua timbira, manterem relações de aliança e por vezes se organizarem conjuntamente em face do Estado e dos colonizadores, algumas de suas experiências históricas foram compartilhadas.

2 Após episódios de sangrenta resistência dos vizinhos Guajajara à empresa evangelizadora, nos anos 1870 e 1896, em que mais de uma dezena de missionários foram mortos, os membros do clero local abandonaram as incursões às aldeias e se dedicaram à população não índia.

3 São elas: Missão Evangélica aos Índios do Brasil e DMG, «Sociedade Missionária Alemã», que também se apresenta como Damit Menschen Gott begegnen, "Povo ao Encontro de Deus".

4 O aspecto coletivo da conversão religiosa entre os povos indígenas das terras baixas sul-americanas foi notado e discutido por Viveiros de Castro (2002a) para a relação dos índios Tupinambá com os jesuítas no século XVII, e por Vilaça (1996) para os Wari' contemporâneos. Crocker (1990:82) indica a conversão de uma liderança entre os Ramkokamekra, que não teve repercussões para o restante da aldeia.

5 Ver, por exemplo, Veiga (2004), Kurtz de Almeida (2004) e Lourenço (2011) para os Kaingang; Cohn (2001) para os Xikrin, dentre outros.

6 Para preservar a identidade das pessoas citadas, os nomes adotados são fictícios.

7 Kupen, termo que nas últimas décadas passou a ser reservado aos colonizadores (chamados, em português, de "brancos", independentemente de sua cor de pele), era utilizado pelos Timbira para denotar uma "forma estranha", um humano não timbira que ainda não fora identificado como membro de outro povo. Assim, ele se opõe diretamente ao termo mehin, "mesma carne", que os Timbira empregam para se autodenominar. Mehin, portanto, parte de um ideal de mutualidade corporal, que implica também uma humanidade compartilhada.

8 O Estatuto da Convenção Interestadual de Ministros e Igrejas da Assembleia de Deus do Serviço de Evangelização das Regiões Tocantins e Araguaia (CIMADSETA) pode ser encontrado em http://www.cimadseta.com.br/site/index.php/estatuto. Acesso em 20/07/2017.

9 Em particular, Maria me relatou outros indícios da identidade étnica de sua ancestral, como o modo de ela de se sentar quando criança (o que Maria ouviu de terceiros) e a dificuldade de adaptação que ela teria apresentado ao chegar em Imperatriz, ainda muito jovem.

10 Os documentos dos índios canela levam o nome não indígena na posição de nome próprio, seguido pelo nome indígena e então o nome de seu povo, a exemplo 
de "Mauro Xoj Canela" ou "Joana Kaprotot Canela". Todos os indígenas recebem um nome "em português" e outro "em canela", como dizem.

11 Ver Crocker (1990:249-257). Para outros povos Jê próximos aos Apanjekra, ver Lopes de Souza (1986), Matta (1976: cap. 3), Melatti (1976), dentre outros.

12 Como é sabido desde Nimuendajú (1946), os povos Timbira apresentam uma organização em metades cerimoniais. Atualmente, os Apanjekra elegem dois pahí (que traduzem por "cacique") e dois "governadores", de modo a contemplar ambas as metades nos cargos de "chefia", incorporando o termo "vice" para definir um dos dois líderes. Este termo não está ligado ao pertencimento a qualquer metade em particular, e frequentemente o "vice" realiza o mesmo trabalho (ou mais trabalho) que o atual pahí ou governador.

13 Essa descrição me foi feita por dois dos principais pajés de Porquinhos. Um deles fora picado por cobras oito vezes e diz que sempre visita a aldeia das cobras, onde viverá depois de morto - as picadas que recebem são de seus futuros parentes-cobra, que querem que ele vá logo viver entre eles. Outro pajé teve sua experiência de quase morte a partir do encontro com o chefe dos porcos, que o fez adoecer para se vingar de uma grande caçada promovida pela aldeia. Os porcos queriam repor alguns dos mortos e assim tentaram capturar um dos caçadores, que negociou sua vida: que o deixassem viver mais um tempo com sua família pois, quando morresse e virasse porco, não teria mais saudade dos mehin e rapidamente os deixaria de ver como gente.

14 Os Apanjekra raramente utilizam o termo genérico para designar um parente (meikwy), sempre especificando de quem se trata: se mãe, tio materno, pai, filho, irmão etc. Apesar de todas as diferenças entre o comportamento esperado de cada membro da família, impera uma solidariedade difusa, e as acusações de mesquinharia dentro de uma família são uma das maiores causas para cismas internos. Os Apanjekra traduzem a palavra ikwynó por companheiro, aplicada àquelas pessoas que realizam tarefas juntas (como caçar e pescar), se ajudam e têm intimidade, dispensando um tratamento formal.

15 Pahpam Gateje é a expressão que os Apanjekra traduzem por "povo de Deus". Gate é um nominalizador e o sufixo je denota o plural. Deste modo, nkrel gate ("cantar" + nominalizador) significa "cantor", gura gate ("matar" + NMZ) é "assassino" e ken gateje ("pedra" + nominalizador + plural) é o etnônimo atribuído à população Timbira que vivia na base das serras da região, o "povo da montanha".

16 Para os Kayapó, os missionários traduziram Deus (ou Jesus) no Novo Testamento por Methindjwy, "senhor dos vivos" (Cohn 2001:21). Na língua wari', Deus se tornou Iri' Jam, o "espírito verdadeiro" (Vilaça 2016:51). Em alguns contextos etnográficos, há a tentativa de associar Deus a um demiurgo existente na mitologia nativa, como entre os Yanomami (na complicada equivalência entre Deus e Omama; ver Leite (2016) e Kopenawa e Alber(t 2015) e entre os Marubo, ver Cesarino (2011:165-166).

17 Para os Apanjekra, plantas também têm agência (espírito e corpo), sendo capazes de intencionalmente enfeitiçar uma pessoa ou auxiliar um xamã a curar al- 
guém. Contudo, não foram mencionadas nas duas versões do mito que obtive, ambas em dezembro de 2013, um mês após a visita de Maria. A primeira versão da "história de Pahpam" que registrei me foi narrada por meu pai de criação, então com quase 40 anos de idade. A segunda versão me foi contada por um de meus nominadores, um homem de pouco mais de 60 anos. Outras duas vezes ouvi este mito em outubro de 2014, ambas versões reduzidas narradas por homens com mais de 40 anos (nestas versões, algumas partes do mito eram omitidas, como os episódios de caça no início da narrativa ou as viagens do macaco), que não consegui registrar inteiramente.

18 Que não é um paradoxo real, uma vez que há um conjunto de técnicas que permitem transformar aquilo que está fora, possibilitando sua incorporação como algo já distinto. As dimensões temporais e espaciais que medeiam o interior e o exterior fazem com que as coisas (ou as pessoas) não estejam dentro e fora simultaneamente, evitando o paradoxo. 


\section{Referências bibliográficas}

CARNEIRO DA CUNHA, Manuela. 1978. Os Mortos e os Outros uma análise do sistema funerário e da noção de pessoa entre os índios Krahô. São Paulo: Hucitec.

1992. "Política Indigenista no Século XIX". In: M. Carneiro da Cunha (org.), História dos Índios no Brasil. São Paulo: Companhia das Letras. pp. 133-154.

CESARINO, Pedro. 2011. Oniska: Poética do Xamanismo na Amazônia. São Paulo: Editora Perspectiva / Fapesp. COELHO DE SOUZA, Marcela. 2001. “Nós, os Vivos: 'construção da pessoa' e 'construção do parentesco' entre alguns grupos jê". Revista Brasileira de Ciências Sociais, v. 16, n. 46:70-96.

2002. O Traço e o Círculo: o conceito de parentesco entre os Jê e seus antropólogos. Tese de Doutorado em Antropologia Social, PPGAS-Museu Nacional, UFRJ.

. 2004. "Parentes de Sangue: Incesto, Substância e Relação no Pensamento Timbira" Mana-Estudos de Antropologia Social, v. 10, n. 1:25-60. $\mathrm{COHN}$, Clarice. 2001. "Índios missionários: Cultos protestantes entre os Xicrin do Bacajá". Campos: Revista de Antropologia Social, Paraná, UFPR, v. 1, n. 1.

CROCKER, William. 1990. The Canela, Eastern Timbira (I): an ethnographic introduction. Washington: Smithsonian Institution Press.

DAMATTA, Roberto. 1976. O Mundo Dividido: a estrutura social dos índios Apinayé. Petrópolis: Vozes.

FAUSTO, Carlos. 2008. "Donos Demais: Maestria e Domínio na Amazônia". Mana: Estudos de Antropologia Social, v. 14, n. 2:329-366.

GOW, Peter. 2009. "Christians: a transfor- ming concept in Peruvian Amazon". In: A. Vilaça \& R. Wright (eds.), Native Christians. Hampshire/ Burlington: Ashgate. pp. 33-52.

HEMMING, John. 2009. Fronteira Amazônica: a derrota dos índios brasileiros. São Paulo: Edusp.

KOPENAWA, Davi \& ALBERT, Bruce. 2015. A Queda do Céu: palavras de um xamã yanomami. São Paulo: Companhia das Letras.

KODAMA, Kaori. 2009. Os Índios no Império do Brasil: a etnografia do IHGB entre as décadas de 1840 e 1860. Rio de Janeiro: Editora Fiocruz; São Paulo: Edusp.

KURTZ DE ALMEIDA, Ledson. 2004. Análise antropológica das igrejas cristãs entre os Kaingang baseada na etnografia, na cosmologia e no dualismo. Tese de Doutorado em Antropologia Social, UFSC.

LEA, Vanessa. 2012. Riquezas Intangíveis de Pessoas Partíveis: os Mebêngôkre (Kayapó) do Brasil Central. São Paulo: Edusp.

LEITE, Tainah. 2016. Ninam (Yanomami) e missionários cristãos no Alto Mucajaí (RR): modos de alteração. Tese de Doutorado em Antropologia Social, PPGAS-Museu Nacional, UFRJ.

LÉVI-STRAUSS, Claude. 2006. A Origem dos Modos à Mesa. São Paulo: Cosac Naify.

LOPES DE SOUZA, Aracy. 1986. Nomes e Amigos: da prática Xavante a uma reflexão sobre os Jê. Série Antropologia, 6. São Paulo: FFLCH/USP.

LOURENÇO, Marília. 2011. A presença dos antigos em tempos de conversão: etnografia dos Kaingang no oeste paulista. Dissertação de Mestrado em Antropologia Social, UFSCar.

MELATTI, Júlio César. 1967. Índios e Criadores: a situação dos Kraho na 
área pastoril do Tocantins. Rio de Janeiro: Monografias do ICS.

. 1976. "Nominadores e genitores: um aspecto do dualismo Krahó". In: E. Schaden (org.), Leituras de etnologia brasileira. São Paulo: Companhia Editora Nacional. pp. 139-48.

NIMUENDAJÚ, Curt. 1946. Eastern Timbira. Berkeley \& Los Angeles: University of California Press.

OVERING, Joanna. 1977. "Comments: symposium 'Social Time and Social Space in Lowland South American Societies". Actes du XLII Congrès International des Américanistes, 2.

OVERING, Joanna (org.). 1985. Reason and Morality. London: Tavistock.

OVERING, Joanna \& PASSES, Alan (orgs). 2000. The Anthropology of Love and Anger. London: Routledge.

PAULA RIBEIRO, Francisco. 2002. Memórias do Maranhão. São Paulo: Siciliano, Coleção Maranhão Sempre.

PERRONE-MOISÉS, Beatriz. 1992. “Índios Livres e Índios Escravos: os princípios da legislação indigenista no período colonial". In: M. Carneiro da Cunha (org.), História dos Índios no Brasil. São Paulo: Companhia das Letras. pp. 115-132.

ROBBINS, Joel. 2004. Becomming Sinners: Christianity and moral torment in a Papua New Guinean Society. Berkeley: University of California Press.

. 2007. "Continuity Thinking and Christian Culture". Current Anthropology, v. 48, n. 1:5-38.

ROBBINS, Joel; SCHIEFFELIN, Bambi \& VILAÇA, Aparecida. 2014. "Evangelical Conversion and the Transformation of the Self in Amazonia and Melanesia: Christianity and the Revival of Anthropological Comparison". Comparative Studies in Society and History, v. 56, n. 3.

SAHLINS, Marshall. 1972. Stone Age
Economics. Chicago/ New York: Aldine, Atherton Inc.

SEEGER, Anthony; DAMATTA, Roberto \& VIVEIROS DE CASTRO, Eduardo. 1979. "A Construção da Pessoa nas Sociedades Indígenas Brasileiras". Boletim do Museu Nacional, n. 32:2-19.

SEEGER, Anthony. 2015. Por Que Cantam os Kĩsedje: uma antropologia musical de um povo amazônico. São Paulo: Cosac Naify.

STOLZE LIMA, Tânia. 2005. Um Peixe Olhou Para Mim: o povo Yudjá e a perspectiva. São Paulo/ Rio de Janeiro: Unesp, ISA e Nuti.

VILAÇA, Aparecida. 1996. "Cristãos sem fé: alguns aspectos da conversão dos Wari' (Pakaa-Nova)". Mana: Estudos de Antropologia Social, v. 2, n. 1:109-137.

. 2002. "Making kin out of others in Amazonia". The Journal of the Royal Anthropological Institute, v. 8, n. 2:347-365.

. 2005. "Chronically Unstable Bodies: reflections on Amazonian corporalities". The Journal of the Royal Anthropological Institute, v. 11, n. 3:445-464.

2016. Preying and Praying: Christianity in Indigenous Amazonia. Oakland: University of California Press.

VIVEIROS DE CASTRO, Eduardo. 1996. "Os Pronomes Cosmológicos e o Perspectivismo Ameríndio". Mana: Estudos de Antropologia Social, v. 2, n. 2:115-144.

. 2002a. "O Mármore e a Murta: sobre a inconstância da alma selvagem". In: - A Inconstância da Alma Selvagem e outros ensaios de antropologia. São Paulo: Cosac Naify. pp. 317-344.

. 2002b. "Imagens da Natureza e da Sociedade na Amazônia". In: 
A Inconstância da Alma Selvagem e outros ensaios de antropologia. São Paulo: Cosac Naify. pp. 181-264.

2002c. "Atualização e contraefetuação do virtual: o processo do parentesco". In: , A Inconstância da Alma Selvagem e outros ensaios de antropologia. pp. 401-55.

2004. "Perspectival Anthropology and the Method of Controlled Equivocation". Tipiti: Journal of the Society for the Anthropology of Lowland South America, v. 2, n. 1:3-22

VEIGA, Juracilda. 2004. "As Religiões Cristãs entre os Kaingang: mudança e permanência" In: R. Wright (org.), Transformando os Deuses: igrejas evangélicas, pentecostais e neopen- tecostais entre os povos indígenas no Brasil. Campinas: Unicamp. pp. 169-97.

WAGNER, Roy. 1977. "Analogic Kinship: a Daribi example". American Ethnologist, v. 4, n. 4:623-642.

WIDLOCK, Thomas. 2013. "Sharing: allowing others to take what is valued". Hau: Journal of Ethnographic Theory, v. 3, n. 2:11-31.

WOODBURN, James. 1998. "Sharing is not a Form of Exchange: an analysis of property-sharing in immediate-return hunter-gatherer societies". In: C. M. Hann (ed.), Property Relation: renewing the anthropological tradition. Cambridge: Cambridge University Press. pp. 48-63. 


\section{A MORAL DE DEUS: DÁDIVA E HUMANIDADE NA VERSÃO APANJEKRA DO CRISTIANISMO}

\section{THE MORAL OF GOD: GIFT AND HUMANITY IN THE APANJEKRA VERSION OF CHRISTIANITY}

\section{Resumo}

Buscando compreender os sentidos que os Canela Apanjekra dão à sua relação com o cristianismo e com os missionários, contextualizo historicamente o contato com os evangelizadores católicos e protestantes e analiso um culto realizado em 2013, na aldeia Porquinhos (TI Porquinhos - MA), por uma comitiva de pentecostais. Os erros de tradução e os equívocos do culto indicam que os mal-entendidos não se limitam a meros problemas linguísticos. Antes, são decorrentes de diferenças ontológicas e éticas que os Apanjekra mantêm em face do cristianismo e, em especial, dos "crentes". Se estas diferenças afastam os Apanjekra da busca pelo telos evangélico, pautado por uma noção de pessoa estranha aos indígenas, elas não impedem um uso pragmático de um código moral que tem por fim a estabilização dos corpos e a manutenção provisória da humanidade e do parentesco.

Palavras-chave: Etnologia Jê, Canela Apanjekra, Cristianismo, Parentesco, Moral, Tradução.

\begin{abstract}
In order to comprehend the meanings that the Canela Apanjekra confer on their relation with Christianity and missionaries, I contextualize their contact with Catholic and Protestant Evangelizers and analyse a service held by a Pentecostal entourage in 2013 in Porquinhos village (Porquinhos Indigenous Land - MA, Brazil). Mistranslations and equivocations during the service indicate that misunderstandings are not limited to mere linguistic issues. Rather, they are due to ontological and ethical differences between the Apanjekra and the Christians, specially the "believers" (Protestants). If these differences move the Apanjekra away from the Evangelical telos, which is based on a notion of 'personhood' that is alien to the Apanjekra, they do not preempt a pragmatical use of its moral code with the aim of bodily stabilization and the provisional maintenance of humanity and kinship

Key words: Jê Ethnology, Canela Apanjekra, Christianity, Kinship, Morality, Translation.
\end{abstract}




\section{LA MORAL DE DIOS: DÁDIVA Y HUMANIDAD EN LA VERSIÓN APANJEKRA DEL CRISTIANISMO}

\section{Resumen \\ Buscando comprender los sentidos que los Canela Apanjekra dan a su relación con el cristianismo y con los misioneros, contextualizo históricamente el contacto con los evangelizadores católicos y protestantes y analizo un culto realizado en 2013, en la aldea Porquinhos (TI Porquinhos - MA), por una comitiva de pentecostales. Los errores de traducción y los equívocos del culto indican que los malentendidos no se limitan a meros problemas lingüísticos. Por el contrario, son consecuencia de diferencias ontológicas y éticas que los Apanjekra mantienen frente al cristianismo y, en especial, a los "creyentes". Si estas diferencias alejan a los Apanjekra de la búsqueda por el telos evangélico, pautado por una noción de persona extraña a los indígenas, no impiden un uso pragmático de un código moral que tiene por fin la estabilización de los cuerpos y el mantenimiento provisional de la humanidad y del parentesco. \\ Palabras clave: Etnología Jê, Canela Apanjekra, Cristianismo, Parentesco, Moral, Traducción.}

